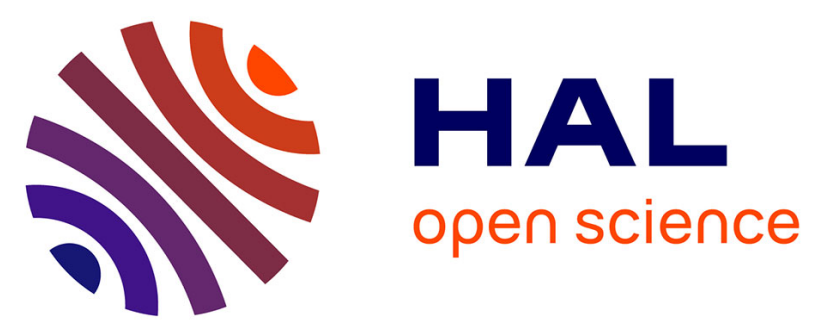

\title{
Comparing the effects of single or trickle experimental infections with Haemonchus contortus on digestibility and host response in naïve Creole kids reared indoor
} Jean-Christophe J.-C. Bambou, Willy W. Cei, Claude C. Barbier, Nathalie Mandonnet, Eliel González García

\section{To cite this version:}

Jean-Christophe J.-C. Bambou, Willy W. Cei, Claude C. Barbier, Nathalie Mandonnet, Eliel González García. Comparing the effects of single or trickle experimental infections with Haemonchus contortus on digestibility and host response in naïve Creole kids reared indoor. Advances in Animal Biosciences, 2010, 1 (2), pp.410. 10.1017/S2040470010000373 . hal-02653543

HAL Id: hal-02653543

https://hal.inrae.fr/hal-02653543

Submitted on 29 May 2020

HAL is a multi-disciplinary open access archive for the deposit and dissemination of scientific research documents, whether they are published or not. The documents may come from teaching and research institutions in France or abroad, or from public or private research centers.
L'archive ouverte pluridisciplinaire HAL, est destinée au dépôt et à la diffusion de documents scientifiques de niveau recherche, publiés ou non, émanant des établissements d'enseignement et de recherche français ou étrangers, des laboratoires publics ou privés. 


\title{
Comparing the effects of single or trickle experimental infections with Haemonchus contortus on digestibility and host response in naïve Creole kids reared indoors
}

\author{
Jean-Christophe Bambou ${ }^{1 \dagger}$, Willy $\mathrm{Cei}^{1}$, Claude Barbier ${ }^{2}$, Nathalie Mandonnet ${ }^{1}$ and \\ Eliel Gonzalez-Garcia ${ }^{3}$ \\ ${ }^{1}$ INRA, UR143 Unité de Recherches Zootechniques, 97170 Petit Bourg (France); ${ }^{2}$ INRA UE 1294 PTEA, site de Gardel, 97160 Le Moule (France); \\ ${ }^{3}$ UMR 868-INRA-ERRC, Campus SupAgro-INRA 34060 Montpellier (France)
}

\section{Introduction}

Gastrointestinal nematodes are a major cause of economic loss in most small ruminant production systems. Chemotherapy is no longer efficient in gastrointestinal nematode control because of dearth of veterinary services in the rural community and high cost of drugs when available has limited this strategy as an effective option for rural producers. It has been shown that improved nutrition is one of the most promising and feasible alternatives to chemotherapy (Coop and Kyriazakis, 1999). However, most of our understanding about the effects of gastrointestinal parasites on ruminant nutrition derives from studies in sheep. In goats, little is known about the mechanisms underlying the relationship between nutrition and gastrointestinal parasitism. In a previous study (see Bambou et al., 2009) we demonstrated the negative effects of an experimental infection with Haemonchus contortus on feed intake (DMI) and digestibility of nutrients in Creole kids. Here we compare the differences between two infection types (single, Sl; and trickle, TI) with $\mathrm{H}$. contortus, based on the fact that $\mathrm{TI}$ better mimics natural infection and the hypothesis that animals may respond differently. Effects on DMI, digestibility, fecal egg count (FEC), circulating eosinophils (EOS) and packed cell volume (PCV) were evaluated in naïve male Creole kids maintained on a similar level of nutrition.

\begin{abstract}
Materials and Methods
The kids were infected over 2 periods of 6 weeks each, differing in immunity stage (PI, 'acquisition of immunity'; Pll, 'expression of immunity'). In PI, 24 kids (19.3 $\pm 0.15 \mathrm{~kg} \mathrm{BW}$ ) were housed in individual boxes, fed a hay-based diet, and a primary experimental infection was induced with a dose of $10,000 \mathrm{~L}_{3}(\mathrm{SI}, n=12)$ or $1,000 \mathrm{~L}_{3} /$ day during ten days $(\mathrm{TI}, n=12)$. In PII, 23 of the initial $24 \mathrm{kids}(22.0 \pm 0$. $\mathrm{kg}$ $\mathrm{BW})$ were submitted to a secondary infection $(\mathrm{SI}, n=11 ; \mathrm{Tl}, n=12)$. Animals were reared indoors with the same management throughout the experiment. For each period, measurements of intake and digestibility were made at 0,3 , and 5 week post-infection (WPI). The DMl and total-tract DM, OM, CP, NDF, and ADF digestibilities were determined using the total feces collection and ad libitum forage supply method. Fecal and blood samples were collected weekly to measure FEC, EOS, and PCV.
\end{abstract}

\section{Results and Discussion}

Infection with $H$. contortus affected DMI, basically during PI, decreasing between WPI 0 and 3 then increasing in WPI $5(P=0.05)$. The infection type affected FEC and PCV $(P<0.001)$ but not DMI. In PI, results in digestibility show an interaction $(P<0.0001)$ between the WPI and infection type, with lower values in SI and at the third WPI; however, such interaction disappeared in PII where animals continued to linearly decrease digestibilities. The FEC were higher $(P<0.001)$ in SI than TI in both periods, and in PI than PII. The results suggest that infection type influenced the intensity through the worm establishment rate and/or female prolificacy stages. However, the effects of these parasites on feed intake and digestibility could not be strictly linked to the infection intensity but more to the immunological stage.

\section{Conclusion}

The results are valuable and the reflection around factors determining the performance in nutrition-parasitism interaction in Creole kids must be continued. This approach must also be evaluated under grazing conditions.

\section{References}

Bambou JC, Arquet R, Archimède H, Alexandre G, Mandonnet N and González-García E 2009. Intake and digestibility of naïve kids differing in genetic resistance and experimentally parasitized (indoor) with Haemonchus contortus in two successive challenges. Journal of Animal Science 87, $2367-2375$.

Coop RL and Kyriazakis I 1999. Nutrition-parasite interaction. Veterinary Parasitology 84, 187-204.

\footnotetext{
${ }^{\dagger}$ E-mail: Jean-Christophe.Bambou@antilles.inra.fr
} 